\title{
JURISPRUDENCIA CONSTITUCIONAL
}

POR

\author{
LUCRECIO REBOLLO DELGADO
}

Profesor Titular de Derecho Constitucional de la UNED

1. RESUMEN DE ACTIVIDAD DEL TRIBUNAL CONSTITUCIONAL DEL AÑO 2003

El Tribunal Constitucional ha dictado durante este periodo un total de 211 resoluciones, distribuidas de la forma que refleja el presente cuadro:

\begin{tabular}{lcccc}
\hline & $\begin{array}{c}\text { RECURSOS } \\
\text { DE AMPARO }\end{array}$ & $\begin{array}{c}\text { RECURSOS DE } \\
\text { INCONSTITUCIONALIDAD }\end{array}$ & CUESTIONES & CONFLICTOS \\
\hline SENTENCIAS & 187 & 11 & 8 & 5 \\
\hline
\end{tabular}

Como es costumbre en esta sección de la Revista, agrupamos el número de recursos de amparo atendiendo al derecho que se dilucida o que es parte central del argumento del Tribunal Constitucional. 


\section{RECURSOS DE AMPARO}

\section{PRINCIPIO DE IGUALDAD Y NO DISCRIMINACIÓN}

STC 98/2003, de 2 de junio

STC 106/2003, de 2 de junio

STC 111/2003, de 16 de julio

STC 140/2003, de 14 de julio

STC 144/2003, de 14 de julio

STC 155/2003, de 15 de septiembre

STC 229/2003, de 18 de diciembre

\section{LIBERTAD DE EXPRESIÓN E INFORMACIÓN}

STC 101/2003, de 2 de junio

STC $117 / 2003$, de 16 de junio

STC 160/2003, de 15 de septiembre

\section{LIBERTAD PERSONAL}

STC 82/2003, de 5 de mayo

STC $94 / 2003$, de 19 de mayo

STC 121/2003, de 16 de junio

\section{DERECHO A LA INTIMIDAD}

STC 127/2003, de 30 de junio

\section{ACCESO A CARGO PÚBLICO}

STC 40/2003, de 27 de febrero

STC 153/2003, de 17 de julio

STC 155/2003, de 21 de julio

STC 176/2003, de 10 de octubre

STC 208/2003, de 1 de diciembre

\section{LIBERTAD SINDICAL}

STC 18/2003, de 30 de enero

STC $88 / 2003$, de 19 de mayo

STC 171/2003, de 29 de septiembre

STC 185/2003, de 27 de octubre

\section{DERECHO DE ASOCIACIÓN}

STC 76/2003, de 23 de abril

STC 96/2003, de 22 de mayo

STC 108/2003, de 2 de junio

STC 120/2003, de 16 de junio

STC 149/2003, de 14 de julio 
STC 162/2003, de 15 de septiembre

STC 183/2003, de 20 de octubre

STC 201/2003, de 10 de noviembre

STC 210/2003, de 1 de diciembre

STC 216/2003, de 1 de diciembre

STC 217/2003, de 1 de diciembre

STC 226 y $227 / 2003$, de 15 de diciembre

\section{INVIOLABILIDAD DEL DOMICILIO}

STC 56/2003, 24 de marzo

\section{LEGALIDAD PENAL}

STC 2/2003, de 16 de enero

STC 13/2003, de 28 de enero

STC 20/2003, de 10 de febrero

STC 161/2003, de 15 de septiembre

STC 193/2003, 27 de octubre

\section{SECRETO DE LAS COMUNICACIONES}

STC 169/2003, de 29 de diciembre

STC 184/2003, de 23 de octubre

\section{DERECHO DE REUNIÓN}

STC 195/2003, de 27 de octubre

\section{PRESUNCIÓN DE INOCENCIA}

STC 52/2003, de 17 de marzo

\section{TUTELA JUDICIAL EFECTIVA}

\section{Recursos electorales}

STC 83/2003, de 5 de mayo

STC $84 / 2003$, de 8 de mayo

STC $85 / 2003$, de 8 de mayo

STC $86 / 2003$, de 8 de mayo

STC 100/2003, de 2 de junio

STC 129/2003, de 30 de junio

STC 131/2003, de 30 de junio

STC 132/2003, de 30 de junio

STC 154/2003, de 17 de julio

\section{Acceso a la justicia}

STC 10/2003, de 20 de enero

STC 24/2003, de 10 de febrero 


$\begin{array}{ll}\text { STC } & \text { 27/2003, de } 10 \text { de febrero } \\ \text { STC } & 59 / 2003 \text {, de } 24 \text { de marzo } \\ \text { STC } & \text { 89/2003, de } 19 \text { de mayo } \\ \text { STC } & 103 / 2003 \text {, de } 2 \text { de junio } \\ \text { STC } & 113 / 2003 \text {, de } 16 \text { de junio } \\ \text { STC } & 143 / 2003 \text {, de } 14 \text { de julio } \\ \text { STC } & 164 / 2003 \text {, de } 29 \text { de septiembre } \\ \text { STC } & 165 / 2003 \text {, de } 29 \text { de septiembre } \\ \text { STC } & 166 / 2003 \text {, de } 29 \text { de septiembre } \\ \text { STC } & 168 / 2003 \text {, de } 29 \text { de septiembre } \\ \text { STC } & 173 / 2003 \text {, de } 29 \text { de septiembre } \\ \text { STC } & 177 / 2003 \text {, de } 13 \text { de octubre } \\ \text { STC } & 179 / 2003 \text {, de } 13 \text { de octubre } \\ \text { STC } & 182 / 2003 \text {, de } 20 \text { de octubre } \\ \text { STC } & 188 / 2003, \text { de } 27 \text { de octubre } \\ \text { STC } & 219 / 2003 \text {, de } 15 \text { de diciembre } \\ \text { STC } & 220 / 2003 \text {, de } 15 \text { de diciembre }\end{array}$

\section{Acceso a los recursos}

$\begin{array}{ll}\text { STC } & 26 / 2003 \text {, de } 10 \text { de febrero } \\ \text { STC } & 35 / 2003 \text {, de } 25 \text { de febrero } \\ \text { STC } & 37 / 2003 \text {, de } 25 \text { de febrero } \\ \text { STC } & 58 / 2003 \text {, de } 24 \text { de marzo } \\ \text { STC } & 66 / 2003 \text {, de } 7 \text { de abril } \\ \text { STC } & 74 / 2003 \text {, de } 23 \text { de abril } \\ \text { STC } & 79 / 2003 \text {, de } 28 \text { de abril } \\ \text { STC } & 105 / 2003 \text {, de } 2 \text { de junio } \\ \text { STC } & 122 / 2003 \text {, de } 17 \text { de junio } \\ \text { STC } & 130 / 2003 \text {, de } 30 \text { de junio } \\ \text { STC } & 139 / 2003 \text {, de } 14 \text { de julio } \\ \text { STC } & 157 / 2003 \text {, de } 15 \text { de septiembre } \\ \text { STC } & 194 / 2003 \text {, de } 26 \text { de octubre } \\ \text { STC } & 214 / 2003 \text {, de } 1 \text { de diciembre } \\ \text { STC } & 225 / 2003, \text { de } 15 \text { de diciembre }\end{array}$

\section{Deficiencias procesales}

$\begin{array}{ll}\text { STC } & 4 / 2003 \text {, de } 20 \text { de enero } \\ \text { STC } & 6 \text { y } 7 / 2003 \text {, de } 20 \text { de enero } \\ \text { STC } & 20 / 2003 \text {, de } 10 \text { de febrero } \\ \text { STC } & 21 / 2003 \text {, de } 10 \text { de febrero } \\ \text { STC } & 28 / 2003 \text {, de } 10 \text { de febrero } \\ \text { STC } & 30 / 2003 \text {, de } 13 \text { de febrero } \\ \text { STC } & 32 / 2003 \text {, de } 13 \text { de febrero }\end{array}$


STC 37/2003, de 25 de febrero

STC 41/2003, de 27 de febrero

STC 44/2003, de 3 de marzo

STC 45/2003, de 3 de marzo

STC 50/2003, de 17 de marzo

STC 51/2003, de 17 de marzo

STC 53,54 y $56 / 2003$, de 24 de marzo

STC 57/2003, de 24 de marzo

STC 60/2003, de 24 de marzo

STC 73/2003, de 23 de abril

STC $75 / 2003$, de 28 de abril

STC 78/2003, de 28 de abril

STC 87/2003, de 19 de mayo

STC 90/2003, de 19 de mayo

STC 91 y $92 / 2003$, de 19 de mayo

STC 91/2003, de 20 de enero

STC 99/2003, de 2 de junio

STC 102/2003, de 2 de junio

STC 107/2003, de 2 de junio

STC 110/2003, de 16 de junio

STC 112/2003, de 16 de junio

STC 114/2003, de 16 de junio

STC $116 / 2003$, de 16 de junio

STC 118/2003, de 16 de junio

STC 126/2003, de 30 de junio

STC 138/2003, de 14 de julio

STC 141/2003, de 14 de julio

STC 159/2003, de 15 de septiembre

STC 163/2003, de 25 de septiembre

STC 167/2003, de 29 de septiembre

STC 181/2003, de 20 de octubre

STC 186/2003, de 27 de octubre

STC 189/2003, de 27 de octubre

STC 191/2003, de 27 de octubre

STC 192/2003, de 27 de octubre

STC 198/2003, de 10 de noviembre

STC 199/2003, de 10 de noviembre

STC 200/2003, de 10 de noviembre

STC 204/2003, de 1 de diciembre

STC 205/2003, de 1 de diciembre

STC 207/2003, de 1 de diciembre

STC 209/2003, de 1 de diciembre 
STC 213/2003, de 1 de diciembre

STC 218/2003, de 15 de diciembre

\section{Ausencia de motivación en la resolución}

STC 93/2003, de 19 de mayo

STC 97/2003, de 2 de junio

STC 104/2003, de 2 de junio

STC 133/2003, de 30 de junio

6. Derecho a la prueba

STC 43/2003, de 3 de marzo

STC 71/2003, de 9 de abril

STC 93/2003, de 19 de mayo

STC 97/2003, de 2 de junio

STC 104/2003, de 2 de junio

STC 133/2003, de 30 de junio

7. Derecho a la defensa

STC 33/2003, de 15 de febrero

STC 36/2003, de 25 de febrero

STC 172/2003, de 29 de septiembre

STC 136/2003, de 30 de junio

\section{Presunción de inocencia}
STC 25/2003, de 10 de febrero
STC 34/2003, de 24 de febrero
STC 65/2003, de 27 de abril
STC 68/2003, de 9 de abril
STC 80/2003, de 28 de abril
STC 135/2003, de 30 de junio
STC 142/2003, de 14 de julio
STC 146/2003, de 14 de julio
STC 174/2003, de 29 de septiembre
STC 187/2003, de 27 de octubre
STC 206/2003, de 1 de diciembre
STC 221 a 224/2003, de 15 de diciembre

9. Derecho a un juez imparcial

STC 38/2003, de 27 de febrero

10.Indefensión

STC $8 / 2003$, de 20 de enero

STC 11/2003, de 27 de enero 


$\begin{array}{ll}\text { STC } & 12 / 2003, \text { de } 28 \text { de enero } \\ \text { STC } & 23 / 2003 \text {, de } 10 \text { de febrero } \\ \text { STC } & 29 / 2003 \text {, de } 13 \text { de febrero } \\ \text { STC } & 67 / 2003, \text { de } 9 \text { de abril } \\ \text { STC } & 69 / 2003, \text { de } 9 \text { de abril } \\ \text { STC } & 170 / 2003 \text {, de } 29 \text { de septiembre } \\ \text { STC } & 178 / 2003 \text {, de } 13 \text { de octubre } \\ \text { STC } & 180 / 2003 \text {, de } 3 \text { de octubre } \\ \text { STC } & 196 / 2003, \text { de } 27 \text { de octubre } \\ \text { STC } & 212 / 2003, \text { de } 1 \text { de diciembre } \\ \text { STC } & 215 / 2003, \text { de } 1 \text { de diciembre }\end{array}$

\section{RECURSOS DE INCONSTITUCIONALIDAD}

STC 1/2003, de 16 de enero. Resuelve el recurso promovido por el Gobierno de la Nación contra determinados incisos de algunos artículos de la Ley 5/1995 de la Asamblea de Extremadura relativa a la función pública de Extremadura. El recurso es estimado. Se formulan tres votos particulares.

STC 3/2003, de 16 de enero. Resuelve el recurso de inconstitucionalidad interpuesto por el Presidente del Gobierno contra la Ley del Parlamento Vasco 1/2002, de presupuestos generales para la Comunidad Autónoma. El Tribunal estima que la citada norma produce una fragmentación de la institución presupuestaria, lo que rompe el principio constitucional de unidad y universalidad presupuestaria. Se formulan varios votos particulares.

STC 16/2003, de 30 de enero. Resuelve el recurso acumulado promovido por el Gobierno de Canarias, el parlamento de Canarias y cincuenta y tres senadores, contra determinados preceptos de la Ley 38/1992 de impuestos especiales. Los recursos son desestimados. Se formula un voto particular.

STC 48/2003, de 12 de marzo ${ }^{1}$. Resuelve el recurso de inconstitucionalidad promovido por el Gobierno vasco contra determinados preceptos de la Ley Orgánica 6/2002, de partidos políticos. El Tribunal desestima el recurso, si bien matiza la interpretación de determinados contenidos de los mismos.

\footnotetext{
${ }^{1}$ Se comenta esta sentencia en el apartado de Resumen de Doctrina.
} 
STC 72/2003, de 10 de abril. Resuelve los recursos de inconstitucionalidad promovidos por el Gobierno de Canarias contra determinados preceptos del Real Decreto-Ley 4/1994 de medidas de carácter fiscal relativa a los vehículos de turismo; y del Gobierno de Canarias contra el Real Decreto-Ley 10/1994. Los recursos son desestimados.

STC 95/2003, de 22 de mayo. Resuelve el recurso interpuesto por el Defensor del Pueblo contra el apartado a) del art. 2 de la Ley 1/1996 de asistencia jurídica gratuita. De forma concreta se recurre el inciso "que residan legalmente en España». El recurso es estimado en virtud de lo cual se concede la asistencia jurídica gratuita a los extranjeros. A esta sentencia se le formulan tres votos particulares.

STC 109/2003, de 5 de junio. Resuelve tres recursos acumulados, promovidos por el Presidente del Gobierno frente a la Ley de Extremadura 2/1996 de atención farmacéutica, y contra la Ley 4/1996 de Castilla la Mancha de ordenación del servicio farmacéutico; y por el Consejo de Gobierno de la Junta de Comunidades de Castilla la Mancha contra la Ley 16/1997 de regulación de los Servicios de las oficinas de farmacia. El recurso resuelve competencias en materia de sanidad, legislación básica y libertad de empresa. El fallo es parcialmente estimatorio.

STC123/2003, de 19 de junio. Resuelve el recurso promovido por el Presidente del Gobierno contra algunos artículos de la Ley de Extremadura 8/1995 (Ley de Pesca). El recurso es estimado declarándose nulos los artículos impugnados.

STC 124/2003, de 20 de junio. Resuelve el recurso de inconstitucionalidad promovido por la Comunidad Foral de Navarra contra varios artículos de la Ley $7 / 996$ de ordenación del comercio minorista y contra los artículos 2 y 3 de la Ley Orgánica 2/1996, complementaria de la anterior. EI recurso es estimado parcialmente. A la presente sentencia se le formulan dos votos particulares.

STC 137/2003, de 3 de julio. Resuelve el recurso promovido por el Gobierno de Canarias contra el artículo 34 del Real Decreto-Ley 12/1995, sobre medidas urgentes en materia presupuestaria, tributaria y financiera y que modificó el tipo de gravamen sobre determinados medios de transporte. Se declara la nulidad del precepto estatal.

STC 152/2003, de 17 de julio. Resuelve el recurso promovido por el Presidente del Gobierno frente a varios artículos de la Ley del Parlamento de Galicia 5/1999, Ley de ordenación farmacéutica. El recurso es parcialmente estimado formulándose un voto particular. 


\section{CUESTIONES DE INCONSTITUCIONALIDAD}

STC 62/2003, de 27 de marzo. Resuelve las cuestiones acumuladas planteadas contra determinados preceptos de la Ley 20/1991 del régimen económico fiscal de Canarias. Las cuestiones son desestimadas.

STC 63/2003, de 27 de marzo. Resuelve la cuestión de inconstitucionalidad planteada frente a determinados preceptos de las leyes 18/1985, 1/1966 y 8/1989. El Tribunal declara la inconstitucionalidad de los preceptos impugnados.

STC 64/2003, de 27 de marzo. Resuelve la cuestión de inconstitucionalidad promovida frente al art. 1.2 y varios contenidos del anexo de la Ley de Responsabilidad Civil y Seguro de los Vehículos a motor. El Tribunal inadmite la cuestión.

STC 81/2003, de 28 de abril. Resuelve las cuestiones acumuladas en relación con algunos incisos del art. 17.3 de la Ley de la Generalidad Valenciana 4/1084 de Hacienda Pública. El Tribunal estima parcialmente la cuestión.

STC 125/2003, de 19 de junio. Resuelve la cuestión planteada por el Tribunal Superior de Justicia del País Vasco en relación con la disposición adicional décima de la Ley 30/1981, reguladora de las formas de matrimonio y procedimientos de nulidad, separación y divorcio. El Tribunal estima la cuestión. Se formula voto particular.

STC 150/2003, de 15 de julio. Resuelve la cuestión planteada por el Tribunal Superior de Justicia del País Vasco en relación con la Ley 22/1993 de medidas fiscales. El Tribunal desestima la cuestión.

STC 197/2003, de 30 de octubre. Resuelve la cuestión promovida por un Juzgado de lo Social respecto del art. 143.2 de la Ley General de Seguridad Social. La cuestión es desestimada por el Tribunal.

STC 202/2003, de 17 de noviembre. Resuelve la cuestión planteada por el Tribunal Superior de Justicia de Madrid en relación con el art. 20 de la Ley 15/1991 de Presupuestos Generales para 1991. La cuestión es desestimada. Se formulan dos votos particulares.

\section{CONFLICTOS DE COMPETENCIA}

STC 151/2003, de 17 de julio. Promovido por el Consejo Ejecutivo de la Generalidad de Cataluña frente al artículo 33.3 del Reglamento General de carreteras. El conflicto es desestimado. 
STC 72/2003, de 10 de abril. Resuelve el conflicto interpuesto por el Gobierno de Canarias contra la Orden del Ministerio de Economía y Hacienda de 20 de abril de 1994. Se desestima la pretensión.

STC 175/2003, de 30 de septiembre. Resuelve el conflicto positivo de competencias planteado por el Consejo Ejecutivo de la Generalidad de Cataluña contra dos ordenes del Ministerio de Industria y Energía del año 1997. El conflicto es estimado parcialmente.

STC 228/2003, de 18 de diciembre. Resuelve el conflicto positivo promovido por la Generalidad de Cataluña contra la Orden de 4 de mayo de 1995 del Ministerio de Administraciones Públicas relativa a ayudas a Planes de Formación. El Tribunal estima parcialmente la pretensión.

STC 230/2003, de 18 de diciembre. Resuelve el conflicto positivo planteado por el Consejo Ejecutivo de la Generalidad de Cataluña contra la resolución de 25 de julio de 2003 de la Dirección General del Instituto Nacional de empleo, relativa a las ayudas para Planes de Formación continua. La pretensión es estimada por el Tribunal, Si bien se formulan varios votos particulares.

\section{RESUMEN DE DOCTRINA}

Muchas son las sentencias relevantes de este año jurisprudencial del Tribunal constitucional, pero ante la tesitura de elegir una, es a nuestro juicio más significativa, la relativa a la Ley Orgánica 6/2002 de partidos políticos, por su repercusión en el ordenamiento constitucional, y en relación a tema tan básico como es el de la regulación de este tipo singular de asociaciones.

De esta forma, la STC 48/2003, de 12 de marzo, resuelve el recurso de inconstitucionalidad promovido por el Gobierno Vasco contra los arts. 1.1, 2.1, 3.2, 4.2 y 3, 5.1, 6 y 9, el Capítulo III (arts. 10 a 12) y la disposición transitoria única, apartado 2, de la Ley Orgánica 6/2002, de 27 de junio, de partidos políticos. Han comparecido y formulado alegaciones el Senado y el Abogado del Estado

Resumimos a continuación los fundamentos del recurso:

a) La demanda se inicia con la exposición de una serie de fundamentos de orden procesal, el primero de los cuales se refiere a la legitimación del Gobierno Vasco para la impugnación de la Ley recurrida. Se justifica aquí, que es doctrina consolidada que una Comunidad Autónoma está legitimada para actuar, no sólo en defensa de su elenco competencial, sino, también, para procurar 
la depuración objetiva del ordenamiento jurídico. En el presente caso, la afección del interés autonómico sería indubitada, a juicio del Gobierno Vasco, y se manifestaría en varios puntos de conexión, a saber:

- La Comunidad Autónoma del País Vasco tiene competencia en "organización, régimen y funcionamiento de sus instituciones de autogobierno dentro de las normas del presente Estatuto" (art. 10.2 EAPV) y

- en «legislación electoral interior que afecte al Parlamento Vasco, Juntas Generales y Diputaciones Forales en los términos previstos en el presente Estatuto y sin perjuicio de las facultades correspondientes a los Territorios Históricos, de acuerdo con lo dispuesto en el artículo 37 del mismo" (art. 10.3 EAPV).

- En consecuencia, para el Gobierno Vasco es innegable la incidencia de la Ley recurrida en el círculo de interés de la Comunidad Autónoma del País Vasco; certeza que se alcanzaría con sólo tomar en consideración que el objeto de aquéIla es la regulación de los partidos políticos, que tienen la función constitucionalmente atribuida de servir de cauce fundamental para la participación política y son, por tanto, vehículos del pluralismo político en tanto a su través se forma y manifiesta la voluntad popular (art. $6 \mathrm{CE}$ ).

Para el recurrente es meridiano que, de acuerdo con la concepción compleja del Estado acogida por la Constitución, una ley con el objeto y el contenido de la aquí recurrida no puede reputarse desconectada del ámbito de interés de ninguna Comunidad Autónoma y, en consecuencia, la regulación de los partidos afecta a su organización institucional o atañe a sus «intereses políticos específicos" (votos particulares a la STC 25/1981). Esta afirmación general cobraría especial sentido para el caso del País Vasco, por ser el ámbito territorial, junto con el de la Comunidad Foral de Navarra, en el que se desenvuelve el partido político que aparece como destinatario principal del contenido más novedoso de la Ley Orgánica de partidos políticos.

b) En lo referente a la fundamentación sustantiva de la demanda, el Gobierno Vasco comienza con una serie de consideraciones introductorias referidas a las circunstancias de la elaboración de la Ley recurrida. Tras recordar los debates que han acompañado a la Ley desde sus inicios y "la polémica que ha suscitado su aplicación práctica y la tensión política y social que existe al respec- 
to, y a la que no es ajena la coincidencia en el tiempo de la iniciación del procedimiento de ilegalización en ella regulado y la suspensión cautelar de las actividades del partido al que se dirige, acordada mediante el correspondiente Auto por el Magistrado Juez que instruye la causa penal contra el mismo en la Audiencia Nacional», el Gobierno Vasco destaca que "el objeto de la LOPP es esencial en un ordenamiento que propugna, expresamente, como uno de sus valores el pluralismo político". Todo lo cual hace que, a su juicio, la impugnación de la Ley de Partidos Políticos "se diferencie notablemente de la de cualquier otra norma legal ... de tal manera, que la connatural tensión entre la voluntad del legislador plasmada en un concreto texto normativo y la del poder constituyente, objetivada en la norma fundamental, adquiere en este caso una dimensión muy cualificada que debe ser ponderada mucho más que en cualquier otro a la hora de contrastar si la primera es respetuosa con la segunda". Ello no obstante, y pese a que "la carga política de la cuestión objeto de litigio merece una atención especial», el Gobierno Vasco advierte de que lo anterior "no es óbice para que esta demanda de inconstitucionalidad se mueva en el terreno estricto de la argumentación constitucional y del rigor jurídico".

c) Entrando ya en consideraciones de fondo, el Gobierno Vasco destaca, en primer término, que la Ley Orgánica de partidos políticos carece de fundamento constitucional. Pone de relieve, a este respecto que durante la elaboración de la Constitución se rechazó expresamente una enmienda que proponía el establecimiento del control de constitucionalidad de los partidos por parte del Tribunal Constitucional. Ese rechazo, reiterado en la discusión de la Ley Orgánica del Tribunal Constitucional, habría supuesto la equiparación de los partidos políticos al régimen común de las asociaciones del art. 22 de la Constitución en todo lo relativo a su control jurisdiccional. Esto es, la aplicación directa de los apartados 2 y 5 de ese artículo, relativos a las asociaciones que persigan fines o utilicen medios tipificados como delito y a las que tengan carácter secreto o paramilitar. El Código penal de 1995 tipificó en su art. 515 el delito de asociación ilícita. Finalmente, la Ley Orgánica 1/2002, de 22 de marzo, del derecho de asociación, ha confirmado, completándolo, el régimen jurídico descrito, con la peculiaridad de que su art. 2.5 extiende a toda clase de asociaciones el requisito de la democracia interna, que la Constitución sólo exigía a los partidos políticos y a otras entidades como sindicatos, organizaciones empresariales y colegios y organizaciones empresariales. 
El Gobierno Vasco sostiene que la Ley recurrida viene a utilizar precisamente como parámetro de la legalidad de la actividad de los partidos —en manifiesta separación del art. 6 CE- una serie de conceptos jurídicos indeterminados que no apelan a la defensa de la norma constitucional, sino, más bien, a la defensa del orden político subyacente. Tal es la consideración que merece, a su juicio, la invocación a los "principios democráticos» (art. 6 LOPP), a los «valores constitucionales expresados en los principios democráticos y en los derechos humanos" (art. 9.1 LOPP), al "régimen de libertades" y al "sistema democrático", al "orden constitucional» y a la "paz pública» (arts. 9.2 y 10.2 c) LOPP). Apelación que denota una pretensión de darles vida autónoma y diferenciada respecto de la norma constitucional; como si fueran algo extraño a ella y pudieran actuar aisladamente de las reglas que establece en relación con el derecho de asociación en partidos políticos (arts. 6 y 22 CE) y sin necesidad de una definición siquiera mínima de su significado

d) El escrito de recurso entra así en un segundo conjunto de consideraciones sustantivas, agrupadas bajo la afirmación de que la Ley impugnada "constituye ejercicio del ius puniendidel Estado". Con ellas se viene a cuestionar, en términos generales, la constitucionalidad de los arts. 9, 10, 11 y 12 de la Ley Orgánica $6 / 2002$, en cuanto vulneran en principio non bis in idem

Para el Gobierno demandante, estamos, en efecto, ante un ejercicio del ius puniendtel Estado entendido en un sentido lato: la disolución es la respuesta del ordenamiento ante una valoración negativa de la actividad del partido. Para llegar a esa conclusión basta con aplicar el criterio seguido por el Tribunal Constitucional para determinar el carácter sancionador de un acto, que consiste en atender a la finalidad perseguida a través de la imposición de la medida restrictiva en la que el acto consiste (SSTC 239/1988, de 14 de diciembre, y 164/1995, de 13 de noviembre; ATC 323/1996, de 11 de noviembre). Así, la cuestión es si la Ley impugnada contempla una segunda sanción, sui gener,i informal o atípica, acumulable a la sanción penal establecida en los arts. 515 y 529 CP.

e) Esta última afirmación da pie para el arranque de una nueva serie de consideraciones impugnatorias agrupadas bajo el aserto de que la Ley impugnada es una ley singular. Enseguida se matiza, sin embargo, que esa condición sólo se predica de una parte de la Ley, centrándose la atención del recurrente en el art. 9 
(»Actividad»), el Capítulo III (»De la disolución o suspensión judicial de los partidos políticos») y en la disposición transitoria única; esta última, no en cuanto implica una previsión que por su naturaleza (transitoria) está llamada a consumar su eficacia aplicativa en el momento de la entrada en vigor de la Ley, sino porque se inscribe en lo establecido en el art. 9 y en el Capítulo III, reforzándolo.

f) La última parte del escrito de recurso se centra en la impugnación de la Ley recurrida por causa de la supuesta infracción del contenido del derecho de asociación. El Gobierno Vasco reitera en este punto que los partidos políticos son asociaciones del art. $22 \mathrm{CE}$ y que el contenido de este precepto conforma el núcleo básico de su régimen constitucional. La Ley impugnada conculcaría ese contenido en varios puntos.

- Así, incurriría en inconstitucionalidad la delimitación del ámbito subjetivo para crear partidos que realiza el art. 1, limitándolo a "los españoles». Esa restricción plantearía dos problemas de constitucionalidad. En primer lugar, entiende el Gobierno Vasco que se incurre en inconstitucionalidad por discriminación de los nacionales de los Estados miembros de la Unión Europea, pues siendo titulares del derecho de sufragio activo y pasivo en las elecciones municipales y en las europeas, negarles de plano la posibilidad de crear partidos conlleva una medida discriminatoria entre iguales (electores y elegibles en dichos comicios) sin justificación. Por lo demás, el art. 2 LODA reconoce a todas las personas, nacionales o no, capacidad para constituir asociaciones; negar a los nacionales de los Estados de la Unión el derecho a crear partidos se revela así como una clara restricción del derecho de asociación, huérfana de fundamento, y aparece como una suerte de "medida de efecto equivalente" que lesiona su derecho a concurrir a las elecciones municipales y europeas en condiciones de igualdad con los nacionales.

- El segundo de los problemas advertidos se refiere a los extranjeros que no son nacionales de Estados de la Unión Europea. El art. 2 LODA - Ley que define el contenido esencial del derecho garantizado por el art. $22 \mathrm{CE}$ - les reconoce también el derecho a crear asociaciones, sin que la restricción del mismo cuando se trata de la creación de un tipo de asociación (el partido político) aparezca fundada.

- También plantea problemas el último inciso del apartado 1 
del art. 2 de la Ley recurrida ("y no hayan sido penalmente condenados por asociación ilícita, o por alguno de los delitos graves»). Cabe entender, en opinión del Gobierno Vasco, que se está imponiendo una pena accesoria ex lege la primera cuestión que se suscita es si el legislador está facultado para hacerlo. Reconociendo que la cuestión no tiene unos perfiles nítidos, se alega que ha de tenerse en cuenta que la Constitución reconoce los derechos fundamentales al condenado a pena de prisión con el único límite "de los que se vean expresamente limitados por el contenido del fallo condenatorio, el sentido de la pena y la ley penitenciaria" (art. 25.2 CE). No hay, por tanto, referencia alguna en la Constitución a que la ley pueda imponer, sin intervención de juez alguno, una limitación de derechos fundamentales como la que aquí se examina. Pero, incluso admitiendo que el legislador pueda hacerlo, en todo caso debería respetar las limitaciones que la Constitución impone. La LOPP ha olvidado, para el Gobierno Vasco, el principio de proporcionalidad, pues la pena no sólo se impone sin atender a los diferentes tipos de delitos contemplados en los Títulos del Código penal a que se refiere el precepto, sino que la opción legislativa adquiere una dimensión más negativa si se toma en cuenta que el objeto de la restricción es el derecho fundamental de asociación en partidos políticos.

g) Por último, y por medio de otrosí, se formula recusación del Excmo. Sr. Presidente del Tribunal Constitucional don Manuel Jiménez de Parga y Cabrera, de conformidad con el art. 219.9 LOPJ.

Mediante escrito registrado en el Tribunal el 25 de octubre de 2002, la Presidente del Congreso de los Diputados comunicó que, aun cuando la Cámara no se personaría en el procedimiento ni formularía alegaciones, ponía a disposición del Tribunal las actuaciones que pudiera precisar.

El escrito de alegaciones del Abogado del Estado se registró en el Tribunal el 4 de noviembre de 2002, del que resumimos su contenido.

a) Como primera alegación se sostiene que el recurso de inconstitucionalidad es extemporáneo. La Ley impugnada se publicó en el "Boletín Oficial del Estado" el 28 de junio de 2002, de manera que el plazo del art. 33.1 LOTC vencía, contando de fecha a fecha (arts. 80 LOTC, 185.1 LOPJ y 5.1 del Código civil), a las veinticuatro horas del 28 de septiembre de 2002, día hábil (sábado). El recurso tuvo entrada en el Registro del Tribunal el 30 de septiembre de 
2002, vencido ya el plazo del art. 33.1 LOTC. Fue presentado en el Juzgado de guardia de Madrid el 27 de septiembre anterior, es decir, el día penúltimo del plazo, cuando era perfectamente posible presentarlo al día siguiente en el Registro del Tribunal.

b) En esa línea, el Abogado del Estado sostiene que la demanda no levanta adecuadamente la carga de alegar, quebrantando así la doctrina constitucional sobre esa materia, y que se resume en la idea de que «no basta la mera invocación formal de los preceptos en la demanda ... o incluso ... la existencia en la misma de una solicitud expresa de su declaración de inconstitucionalidad, para que este Tribunal deba pronunciarse sobre todos y cada uno de ellos, sino que es preciso, además, que en el cuerpo del recurso se contenga la argumentación específica o razonamientos que fundamenten la presunta contradicción de éstos con la Norma fundamental" (STC 233/1999, FJ 2). Para demostrar que el Gobierno Vasco no levanta esa carga, el Abogado del Estado contrasta los preceptos recurridos con los argumentos de inconstitucionalidad ofrecidos por el actor.

c) El escrito de alegaciones del Abogado del Estado pasa a examinar, a continuación, de manera particularizada, los distintos fundamentos materiales del recurso.

- El Abogado del Estado no admite que la Ley recurrida carezca de fundamento constitucional. Tal fundamento se encontraría, en su opinión, en el art. 81.1, en relación con los arts. 6, 22 y 23, todos ellos de la Constitución.

Para el Abogado del Estado, no puede aceptarse, por tanto, que una asociación (incluidos los partidos) sólo puede disolverse judicialmente cuando merezca la calificación de asociación ilícita en el sentido del art. 515 del Código penal. Con semejante interpretación se convertirían en normas imperfectas - esto es, se dejarían sin protección judicial- los mandatos constitucionales de estructura y funcionamiento democráticos y de respeto a la Constitución y a la ley (arts. 6 y 10.1 CE). Los partidos serían así los únicos sujetos jurídicos impunes ante cualquier infracción del ordenamiento, incluidos los mandatos y deberes que el constituyente especialmente les impuso, con tal de que no fueran asociaciones ilícitas penalmente perseguibles. A diferencia de las demás personas físicas y jurídicas, sólo estarían obligados a respetar la ley penal.

- El segundo grupo de consideraciones sustantivas realizadas 
por el Abogado del Estado se articula sobre la idea de que la declaración de ilegalidad y la disolución de un partido en virtud de lo dispuesto en los apartados 2 y 3 del art. 9 LOPP nada tiene que ver con el ius puniendyide que no hay infracción del principio non bis in idefEn este sentido, se recuerda, con cita de la STC 164/1995, de 13 de noviembre, FJ 4, que no cabe «extender indebidamente el concepto de sanción con la finalidad de obtener la aplicación de las garantías constitucionales propias de este campo a medidas que no responden verdaderamente al ejercicio del ius punienddiel Estado".

- El escrito de alegaciones del Abogado del Estado se detiene a continuación en el examen de la supuesta naturaleza singular o de caso único de la Ley recurrida. En su opinión, de la doctrina constitucional en la materia, se desprende que la LOPP no puede ser tachada de ley de caso único, ni en su totalidad ni en ninguno de sus artículos. Es una Ley general y abstracta, que no ciñe su posible aplicabilidad a un supuesto de hecho concreto ni su contenido y eficacia se agotan en la singular medida adoptada para aquel supuesto. No cabe negar, por ser notorio, que la configuración de los apartados 2, 3 y 4 del art. 9 LOPP se ha hecho teniendo en cuenta la trayectoria y actividad de un notorio partido político vasco, pero ello no hace de la LOPP ni de esos concretos apartados una ley de caso único. Se confunde aquí la ocasión que da motivo a que se impulse la aprobación de una ley con el alcance objetivo que en sí misma tiene la Ley aprobada

- La última parte del escrito de alegaciones tiene por objeto razonar sobre la conformidad de la Ley con el artículo 22 de la Constitución. Por lo que hace a la reserva del derecho de crear partidos a los nacionales españoles (art. 1.1 LOPP), sostiene el Abogado del Estado que la diferencia de tratamiento entre españoles y extranjeros en ese punto se justifica constitucionalmente en el art. 13.1 CE. Los partidos son, ante todo, organizaciones electorales. La mediación política que llevan a cabo entre Estado y sociedad tiene lugar, sobre todo, a través de mecanismos electorales. Ahora bien, con la posible excepción de las elecciones municipales y europeas, el art. 13.2 CE dispone que sólo los españoles serán titulares de los derechos del art. $23 \mathrm{CE}$. En virtud de esta regla, y con las salvedades señaladas, "no cabe ..., ni por tratado ni por ley, atribuir el derecho de sufragio pasivo a los no nacionales en cualquiera de los procedimientos electorales para la integración 
de órganos de los poderes públicos españoles" (DTC de 1 de julio de 1992, FJ 3 A). Todo ello justifica que la Ley impugnada, como antes la Ley 54/1978, reserve a los españoles la creación de estos importantes actores electorales. Por otro lado, no existe norma europea que imponga al legislador español la obligación de reconocer a los nacionales de la Unión el derecho de libre creación de partidos políticos españoles. Y lo dispuesto en el art. 1.1 LOPP no puede considerarse una restricción que amenace seriamente el derecho de sufragio pasivo en las municipales y europeas de los nacionales de la Unión residentes en España.

El escrito de alegaciones del Senado se registró en el Tribunal el 5 de noviembre de 2002. Por lo que hace a las cuestiones de orden procesal, el Letrado de las Cortes Generales representante de la Cámara sostiene, en primer término, que las alegaciones del recurrente en relación con su legitimación precisan de algunas matizaciones. En particular, admitiendo la evidente evolución jurisprudencial en materia de legitimación, se alega que es discutible que desde las competencias autonómicas sobre organización, régimen y funcionamiento de las instituciones autonómicas (art. 10.2 EAPV) y sobre legislación electoral interna (art. 10.3 EAPV) se pueda ubicar en el ámbito propio de interés de la Comunidad Autónoma del País Vasco cualquier norma que, como es el caso, ataña de forma directa al derecho fundamental del art. 23.1 CE.

Continúa argumentando, que la regulación del desarrollo directo de los elementos esenciales de un derecho fundamental es un ámbito reservado a la ley orgánica (art. 81.1 CE). El interés legítimo de la Comunidad Autónoma no estriba en su conexión con la afectación del derecho a formar partidos políticos como especie del género asociación, sino en el juego de los arts. 9.2 y 139 CE. Esto es, por la obligación que pesa sobre todo poder público en orden a la promoción positiva de las condiciones para que la libertad y la igualdad sean reales y efectivas, desde los valores proclamados en los arts. 1 y 139 CE. En relación con la afirmación del Gobierno Vasco en el sentido de que la Ley impugnada tiene un especial sentido para la Comunidad Autónoma del País Vasco por desenvolverse en su ámbito territorial y en el de la Comunidad Foral de Navarra el partido que aparece como destinatario principal de aquéIla, se alega de contrario que se trata de una afirmación infundada, pues no estamos en presencia de una ley singular, como más adelante se razona con detalle.

Las alegaciones de carácter sustantivo se ordenan, a continuación, de acuerdo con los apartados en los que se agrupan los argumentos del 
recurrente. Así, y por lo que hace a las razones recogidas en la "Introducción», el representante procesal del Senado manifiesta su extrañeza por las afirmaciones del Gobierno Vasco, en las que se mezcla el discurso jurídico propio de un recurso de inconstitucionalidad con el análisis sociológico o politológico. Para la Cámara, no es cierto que el presente caso se distinga de otros por presentar una especial carga política. Más bien parece que el recurso confunde la realidad con el deseo e incluso en éste hay confusión, pues se demanda habitualidad jurídica mientras se aportan argumentos metajurídicos.

a) Por lo que hace a la supuesta carencia de fundamento constitucional por parte de la Ley recurrida, alega la Cámara que los constituyentes no adoptaron el control específico de constitucionalidad de los partidos por parte del Tribunal Constitucional, pero sí incorporaron, por mor de la enmienda transaccional que daría lugar al art. $6 \mathrm{CE}$, una concepción "militante» del concepto de la democracia partidista y, a sensu contrałlabexclusión de quienes, aun aceptando formalmente la concepción democrática, Ilevan a cabo acciones atentatorias contra la normal marcha de la actividad estatal. En segundo lugar, tampoco sería tan automática la conclusión de que la inexistencia de un control específico de la constitucionalidad de los partidos suponga la equiparación de éstos a las asociaciones comunes (es decir, aplicación del art. 22.2 y 5 CE, del art. 515 CP y del art. 2.5 de la Ley Orgánica 1/2002, de 22 de marzo, reguladora del Derecho de Asociación). Basta señalar que el art. 1.3 LODA dispone que los partidos se regirán por su legislación específica, y tal es, precisamente, la LOPP, como antes lo fue la Ley 54/1978, cuya inconstitucionalidad quedó descartada en la STC 10/1983, de 21 de febrero.

b) A propósito de las razones agrupadas por el Gobierno Vasco bajo la afirmación genérica de que la Ley impugnada constituye ejercicio del ius puniendél Estado, alega la Cámara que la Ley contiene, además de muchas otras prescripciones, muestras de ese ejercicio. Pero matizando a continuación que se trata de ius puniendi en sentido lato, esto es, más allá del Derecho penal, en el que no se agota ese i us También comparte la Cámara que la disolución es la respuesta ante una valoración negativa, pero no de la actividad del partido, sino ante actividades de un partido que atenta contra el ordenamiento constitucional. De lo uno a lo otro va tanto como decir que la LOPP es una ley punitiva a decir de ella que regula la organización y funcionamiento de los partidos y, entre otras cosas, prevé un régimen sancionatorio para supuestos de contravención 
grave y reiterada del ordenamiento constitucional.

c) El Senado discute la afirmación de que la Ley impugnada es una ley singular. En su opinión, se trata de una norma que, con carácter general, regula los aspectos principales de los partidos políticos, en la misma línea que la Ley de 1978, que fue declarada plenamente constitucional en su momento. Tampoco sería cierta la denunciada falta de vocación reguladora del fraude de ley, pues la improcedencia de la continuidad o sucesión de un partido disuelto con fraude de ley afecta a los que lo han sido por funcionamiento antidemocrático tanto interno como externo. Por su parte, la supuesta retroactividad de la Ley no es tal, pues las actividades que pueden dar lugar a la declaración de ilicitud y disolución son sólo las realizadas con posterioridad a la entrada en vigor de la Ley y también respecto de partidos ya existentes o constituidos ad hocen el umbral de la vigencia para eludir su aplicación. Por último, las especialidades procesales de la Ley responden, en opinión del Senado, a una legítima opción del legislador orgánico, entre varias posibles. Lo mismo cabe decir, en particular, a propósito de la iniciativa concedida a las Cámaras para instar al Gobierno la solicitud de ilegalización, sin que pueda admitirse que se quiebre el régimen de relaciones interorgánicas previsto en la Constitución. Si acaso, se potencia la posición del Parlamento en la red de poderes del Estado, en términos acordes con la forma política del Estado establecida en el art. 1.3 CE.

d) Finalmente, el escrito de alegaciones razona que la Ley recurrida no conculca el contenido del derecho de asociación. El recurso parte, para el Senado, de una equiparación errónea entre partidos políticos y asociaciones del art. $22 \mathrm{CE}$. Una cosa es que el derecho de formar partidos sea una variable específica y singular del derecho de asociación, lo que, entre otras cosas, puede facultar para recurrir en amparo en materia de derecho de asociación, y otra, bien distinta, que la regulación de los partidos sea, sin más, la propia del derecho de asociación. La regulación específica de los partidos es la establecida en la Constitución (art. 6) e integrada por la LOPP, además de la normativa también específica sobre financiación, siendo la LODA normativa supletoria que, como tal, sólo actúa en ausencia de norma específica, que, en lo tocante a los partidos, es, precisamente, la Ley impugnada.

Por todo lo expuesto, el Senado interesa que se dicte Sentencia des- 
estimatoria del presente recurso de inconstitucionalidad.

Por Auto de 20 de noviembre de 2002, el Pleno del Tribunal desestimó la recusación formulada por el Gobierno Vasco contra el Presidente del Tribunal don Manuel Jiménez de Parga y Cabrera.

Por diligencia de 27 de noviembre de 2002, el Secretario de Justicia hace constar que, finalizado el incidente de recusación en sentido desestimatorio, pasa el recurso al Excmo. Sr. Presidente don Manuel Jiménez de Parga y Cabrera, a quien inicialmente había correspondido la ponencia.

Muchos son los fundamentos jurídicos de esta sentencia (22 en total). Si bien no son jurídicamente unos más importantes que otros, y dado lo complejo de todos ellos, hemos creído más conveniente entresacarlos, y de esta forma ir viendo como argumenta su fallo el Tribunal a las cuestiones claves planteadas en el recurso del Gobierno Vasco.

1. La primera cuestión que resuelve el Tribunal es la relativa a si los partidos, en tanto que especie del género asociación, no admiten más límites y controles que los previstos en la Constitución para las asociaciones (art. $22 \mathrm{CE}$ ) o si su reconocimiento constitucional en los términos del art. 6 CE implica la existencia de límites y condiciones adicionales, sean propiamente constitucionales o el resultado de una eventual habilitación al legislador orgánico por parte del constituyente. Ante esta interrogante, el Tribunal manifiesta con rotundidad, que como alegan el Abogado del Estado y el representante del Senado, la respuesta se encuentra en los arts. 53.1 y $81.1 \mathrm{CE}$, en relación con los arts. 20, 22 y $23 \mathrm{CE}$. Continúa manifestando el Tribunal, que la posibilidad de la regulación de los partidos políticos fuera del texto de la Ley de asociaciones está incluso prevista en el art. 1.3 de ésta. Si no hay obstáculo constitucional alguno para la existencia de la Ley de asociaciones, mal puede haberlo para la de partidos políticos. Respecto de éstos, el art. 6 CE contiene unas exigencias de respeto a la Constitución y a la ley, no mencionadas en su especificidad en el art. $22 \mathrm{CE}$, aunque en todo caso a éstas les afecta la previsión genérica en el mismo sentido del art. 9.1 CE, lo que justifica, en impecables términos constitucionales, la inclusión en el ordenamiento de una Ley que regule los partidos políticos.

De esta forma, para el Tribunal constitucional la "cualificación funcional no desvirtúa la naturaleza asociativa que está en la base de los partidos, pero eleva sobre ella una realidad institucional diversa y autónoma que, en tanto que instrumento para la participación política en los procesos de conformación de la 
voluntad del Estado, justifica la existencia de un régimen normativo también propio, habida cuenta de la especificidad de esas funciones. La relevancia constitucional de los partidos les viene dada por pretender un fin cualificado de interés público y de cuya aspiración se sirve el Estado para proveer a la integración de los procedimientos de formación de la voluntad general. La libertad característica de las asociaciones, y de la que los partidos también disfrutan, no puede ser para éstos tan omnímoda que a su amparo se desvirtúen como instrumentos para la consecución de sus fines constitucionales".

Así, la diversificación de regímenes normativos entre una disciplina general para las asociaciones comunes (actualmente contenida en la Ley Orgánica 1/2002, reguladora del derecho de asociación) y otra específica para las asociaciones cualificadas por la relevancia constitucional de su función política (la referida hoy en la Ley impugnada y antes en la Ley 54/1978, de partidos políticos) es plenamente conforme con los arts. 6 y 22 CE. Por lo que hace a la disciplina normativa contenida en la nueva Ley de partidos, el Gobierno Vasco, fuera de la descalificación de la pretensión del legislador orgánico de establecer límites distintos de los establecidos en el art. $22 \mathrm{CE}$, no impugna en concreto ninguno de tales límites adicionales. Con carácter general alude sólo a la supuesta asunción por la Ley recurrida de un modelo de democracia militante, en virtud del cual se impondría como límite a los partidos la necesidad de comulgar con un determinado régimen o sistema político, más allá del respeto al texto constitucional.

2. Aborda en segundo lugar el Tribunal, el argumento esgrimido por el Gobierno Vasco de que la Ley Orgánica 6/2002 "constituye el ejercicio del ius puniendál Estado", cuestionándose, en términos generales, la constitucionalidad de los arts. 9, 10, 11 y 12 de la Ley impugnada. Como ya recogimos, en su opinión, la Ley añade una nueva sanción a la ya establecida en los arts. 515 y 529 del Código penal, vulnerando así el principio non bis in idẹm tanto en su dimensión material como en la procesal, pues no se impide la sustanciación simultánea de dos procesos sancionadores.

Al respecto de esta circunstancia el Tribunal entiende que debe delimitar el concepto de non bis in iderA este respecto cabe señalar que de vulneración de dicho principio, como extensamente se expone en nuestra STC 2/2003, de 16 de enero, sólo 
cabe hablar técnicamente cuando en concreto se produce un doble castigo de un mismo sujeto o se le somete a un doble procedimiento punitivo. De modo que, en el plano normativo, sólo puede hablarse de vulneración del bis in idenen un sentido impropio, cuando las normas enjuiciadas obliguen a imponer una doble sanción penal o equivalente por los mismos hechos o a tramitar un doble procedimiento punitivo contra una misma persona. Se podría argumentar que éste es, precisamente, el caso; pero el Gobierno Vasco no justifica que lo sea, limitándose, en este punto, a decir que no se impide la sustanciación simultánea de dos procesos sancionadores. Frente a lo que cabría oponer que tales procesos no se dirigen contra el mismo sujeto (pues en el caso de la Ley de partidos la demandada será una determinada organización política con absoluta independencia de las personas que la componen mientras que en los supuestos tipificados como delito en el Código penal los acusados serán personas físicas).

Continúa manifestando el Tribunal, que «bastaría lo anteriormente aducido para desestimar la infracción del principio non bis in idem que se esgrime contra los arts. 9, 10, 11 y 12 LOPP. Sin embargo, parece conveniente contestar a las demás alegaciones con las que el recurrente trata de fundamentar la vulneración del referido principio». De esta forma, se argumenta en contra del recurso, que "la ilegalización y disolución de un partido político es, desde luego, una consecuencia jurídica gravosa para el partido mismo, para sus afiliados y, por extensión, también para sus simpatizantes y votantes. Ello no las convierte, sin más, en medidas punitivas, pues en otro caso habría que conceder, como alega el Abogado del Estado, que toda consecuencia jurídica desfavorable o la simple denegación de un beneficio encerraría un componente sancionador".

El control jurídico de esa vertiente definidora de la asociación como partido, consistente en el respeto a las exigencias del ordenamiento jurídico democrático recogidas en el art. 6 CE ha de ser, por necesidad, un control a posteriarle modo que, al faltar dichas exigencias y producirse una situación de quebranto del orden jurídico pluralista proclamado por la Constitución, se hace preciso restablecer la legalidad conculcada. No hay, por tanto, componente punitivo alguno. Estamos, pues, ante una sanción reparadora, que cabe incluir entre aquéllas a las que el propio Código penal niega el carácter de penas (art. 34), por lo que, tal y como anticipábamos, debemos desestimar las vulneración del principio non bis in idem 
3. Una tercera respuesta al recurso de inconstitucionalidad la constituye la argumentación entorno a algunos de los preceptos de los arts. 9, 10, 11 y 12 LOPP por entender que vulneran los derechos fundamentales de libertad ideológica, participación, expresión e información, en la medida en que consagran una "democracia militante». Esa impugnación se limita a las conductas que, a juicio del Gobierno Vasco, no son punibles y se basa en una interpretación aislada de algunos de los supuestos contenidos en el art. 9.3.

A ello argumenta el Tribunal, que "para responder a la impugnación planteada por el Gobierno Vasco ha de efectuarse previamente una descripción del sistema que constituyen los tres primeros números del art. 9 LOPP. En el primero se habla, no de ninguna clase de vinculación positiva, sino del simple respeto a los valores constitucionales, respeto que ha de guardarse por los partidos en su actividad y que es compatible con la más plena libertad ideológica. En el número 2 se subraya que un partido será declarado ilegal solamente "cuando su actividad vulnere los principios democráticos, particularmente cuando con la misma persiga deteriorar o destruir el régimen de libertades o imposibilitar o eliminar el sistema democrático, mediante alguna de las siguientes conductas, realizadas de forma reiterada y grave", y a continuación se enumeran, en los apartados a), b) y c), los requisitos genéricos que ha de reunir la conducta de los partidos para poder fundamentar la declaración de ilegalidad.

Ha de admitirse, con el Gobierno Vasco, que, en efecto, al "vulnerar sistemáticamente las libertades y derechos fundamentales, promoviendo, justificando o exculpando los atentados contra la vida o la integridad de las personas, o la exclusión o persecución de personas por razón de su ideología, religión o creencias, nacionalidad, raza, sexo u orientación sexual», tal como reza la letra a) del art. 9.2 LOPP, se realizan conductas que pueden tener encaje en preceptos como los arts. 515, 576 y 578 del Código penal. Y que lo mismo puede decirse de las descritas en las letras b) ("fomentar, propiciar o legitimar la violencia como método para la consecución de objetivos políticos o para hacer desaparecer las condiciones precisas para el ejercicio de la democracia, del pluralismo y de las libertades públicas") y c) del propio art. 9.2 (»complementar y apoyar políticamente la acción de organizaciones terroristas para la consecución de sus fines de subvertir el orden constitucional o alterar gravemente la paz pública, tratando de someter a un clima de terror a los poderes públicos, a determinadas personas o grupos de la sociedad o a la población 
en general, o contribuir a multiplicar los efectos de la violencia terrorista y del miedo a la intimidación generada por la misma»).

Hay que admitir, con el recurrente, manifiesta el Tribunal, que la coincidencia entre el art. 9.2 y la ley penal no es absoluta; también hay que dejar sentado que en ningún momento se hace referencia a programas o ideologías sino a actividades de colaboración o apoyo al terrorismo o la violencia. En consecuencia, no se abre ningún resquicio a la que se ha llamado "democracia militante" y no hay, por consiguiente, vulneración alguna de las libertades ideológica, de participación, de expresión o de información.

En cuanto al número 3 del art. 9 LOPP, la defectuosa redacción de su encabezamiento puede hacer pensar que las conductas en él enumeradas se sobreañaden a las descritas en el número anterior y que, por lo tanto, han de ser interpretadas con independencia de ellas. Sin embargo, la interpretación sistemática de ambos preceptos y la de todo el artículo en el que se incardinan obliga a entender que en las conductas descritas en el número 3 del art. 9 han de concurrir los rasgos genéricos a que se refiere el número 2 del mismo precepto. Las conductas enumeradas en el art. 9.3 LOPP no son sino una especificación o concreción de los supuestos básicos de ilegalización que, en términos genéricos, enuncia el art. 9.2 de la propia Ley; de tal manera que la interpretación y aplicación individualizada de tales conductas no puede realizarse sino con vinculación a los referidos supuestos contenidos en el art. 9.2.

Esto sentado, y sin que nos corresponda ahora determinar si la mera ausencia de condena puede ser o no entendida como apoyo implícito al terrorismo, lo cierto es que la legitimación de las acciones terroristas o la exculpación o minimización de su significado antidemocrático y de la violación de derechos fundamentales que comportan puede llevarse a cabo de modo implícito, mediante actos concluyentes, en determinadas circunstancias, siendo claro que, en tales supuestos, no puede hablarse de vulneración de la libertad de expresión.

Idénticas consideraciones son aplicables en el art. 9.3 d) LOPP, que así entendido deja de ser una simple manifestación ideológica para convertirse en un acto de colaboración con el terrorismo o la violencia. Ciertamente, la utilización de los instrumentos a que se refiere el precepto que examinamos comporta la emisión de un mensaje; pero, como dijimos en la STC 136/1999, de 20 de 
julio, "con todo, aun teniendo muy presentes estas cautelas, no puede negarse la posibilidad de que existan mensajes que, aun sin hallarse incursos en alguno de los tipos penales de amenazas o coacciones, puedan considerarse intimidatorios, porque anuden, explícita o implícitamente, pero de modo creíble, la producción de algún mal grave o la realización o no realización de determinada conducta por parte del destinatario. Este tipo de mensajes no queda amparado por las libertades de expresión o de información" (FJ 16).

Y lo mismo cabe decir, en general, respecto a la previsión contenida en la letra c) del art. 10.2 LOPP: "Cuando de forma reiterada y grave su actividad vulnere los principios democráticos o persiga deteriorar o destruir el régimen de libertades o imposibilitar o eliminar el sistema democrático, mediante las conductas a que se refiere el art. 9». También aquí es necesario señalar que el precepto se circunscribe a la actividad de los partidos políticos, sin extenderse a sus fines u objetivos programáticos. Por tanto, en los términos de este precepto, sólo incurre en causa de disolución el partido que, no en su ideología, sino en su actividad persiga efectiva y actualmente "deteriorar o destruir el régimen de libertades".

En conclusión, la interpretación sistemática del art. 9, entendiendo los supuestos del apartado 3 como especificaciones del género de conductas descritas en el apartado 2, permite descartar que, al configurar aquéllos como supuestos a partir de los cuales puede llegarse a la disolución de un partido político, se hayan vulnerado las libertades ideológicas, de participación, de expresión o de información.

4. El Gobierno Vasco impugna también los supuestos de posible ilegalización contemplados en el art. 9 LOPP desde la perspectiva de la proporcionalidad y, finalmente, desde la de la previsibilidad.

Invirtiendo el orden de la impugnación, la calificación de excesiva generalidad e imprevisibilidad que el Gobierno Vasco anuda específicamente a los supuestos contemplados en los apartados f) y g) del art. 9.3 queda, en buena parte, enervada desde el momento en que hemos dejado establecido que tales supuestos han de ser interpretados como especificaciones de alguno de los apartados a), b) o c) del art. 9.2.

Precisado el apartado f) queda, a la vez, delimitado el campo de aplicación del g). El apoyo desde las instituciones a que se refiere el apartado g) es el apoyo específicamente dirigido a asociaciones que, directa o indirectamente, amparan el terrorismo o la 
violencia y, justamente, con el objetivo de reforzar esa actividad ilegítima. Sólo entendida así, la conducta descrita en el apartado g) puede inscribirse en el marco establecido por el art. 9.2.

Por todo ello, argumenta el Tribunal, la impugnación del Gobierno Vasco debe desestimarse en este punto.

5. El Gobierno Vasco impugna los arts. 9 y 10 LOPP en virtud de la desproporción que a su juicio se produce, en los casos en que los supuestos contemplados en dichos preceptos no describan conductas constitutivas de delito al aplicar a los mismos, sin gradación alguna, la sanción de disolución. El Gobierno Vasco entiende que se trata de una medida desproporcionada, por cuanto no cabe modularla en función de la verdadera entidad de la causa eventualmente concurrente. En su opinión, la Ley no permite la imposición de una sanción proporcionada a las circunstancias del caso, siendo deseable que se hubieran establecido medidas disuasorias o preventivas, con una intensidad menor, para contribuir a evitar que el partido siga por una vía que, de persistir, podría conducir a su disolución.

El Gobierno Vasco limita, pues, su impugnación a aquellos supuestos en que la conducta descrita en la Ley Orgánica de partidos políticos no pueda incardinarse en ninguno de los incisos del art. 10.2, anteriormente reseñados. "Respecto a los bienes o intereses que el precepto examinado pretende proteger".

A estas objeciones, responde el Tribunal que ninguna de las conductas descritas en el art. 9 LOPP determina aisladamente la disolución: para que ésta pueda tener lugar, es preciso que sean realizadas "de forma reiterada y grave" como precisa el encabezamiento del art. 9.2. En segundo lugar, que la existencia de un partido que con su actividad colabore o apoye la violencia terrorista, pone en peligro la subsistencia del orden pluralista proclamado por la Constitución; $y$, frente a ese peligro, no parece que pueda aplicarse otra sanción reparadora del orden jurídico perturbado que la disolución. Por último, ha de destacarse que el art. 6 CE contiene una configuración constitucional de partido: en la Constitución, un partido, para merecer la condición de tal, ha de poder ser expresión del pluralismo político y, por lo tanto, no es constitucionalmente rechazable que un partido que con su actuación ataca al pluralismo, poniendo en peligro total o parcialmente la subsistencia del orden democrático, incurra en causa de disolución.

6. En el fundamento jurídico 14 , analiza el Tribunal Constitucional el argumento del Gobierno Vasco, de que la Ley Orgánica 6/2002 en una ley de carácter singular. Los preceptos así impugnados son 
el art. 9 ("Actividad») y los contenidos en el Capítulo III ("De la disolución o suspensión judicial de los partidos políticos») y en la disposición transitoria única.

Para el Gobierno Vasco, la Ley Orgánica 6/2002 respeta formalmente el principio de generalidad de la ley, pero es claro que, desde el punto de vista material, se ha concebido para perseguir una determinada formación política, única a la que, en realidad, resultaría aplicable. Prueba de la carencia de una voluntad reguladora general se encontraría, en opinión del recurrente, en la disciplina del fraude de ley contenida en su art. 12.3 y en la disposición transitoria única, claramente lesiva del principio de irretroactividad proclamado en el art. 9.3 de la Constitución. También harían de la Ley una norma singular sus especialidades procesales, tanto en lo que se refiere al Tribunal competente como a la legitimación para instar el proceso de disolución, pasando por el régimen excepcional que se introduce en el sistema de recursos de la Ley Orgánica de régimen electoral general.

Antes de iniciar el fundamento jurídico, repasa el Tribunal su jurisprudencia al respecto del concepto de "leyes singulares" o "leyes de caso único", recordando que son "aquéllas dictadas en atención a un supuesto de hecho concreto y singular, que agotan su contenido y eficacia en la adopción y ejecución de la medida tomada por el legislador ante ese supuesto de hecho, aislado en la ley singular y no comunicable con ningún otro" (STC 166/1986, de 19 de diciembre, FJ 10; en el mismo sentido, ATC 291/1997, de 22 de julio). Para manifestar a continuación que «la Ley impugnada no sólo es general formalmente por el modo en que se halla formulada; sino que también lo es materialmente, en tanto contempla, en abstracto, una serie de conductas cuya realización en forma reiterada y grave podría determinar la disolución de cualquier partido presente o futuro". De esta forma, para el Tribunal, la Ley Orgánica 6/2002 no es el resultado de un ejercicio excepcional de la potestad legislativa del Estado, como sostiene el Gobierno Vasco, sino que su generalidad y abstracción hacen de ella expresión de un ejercicio correcto y normal de la función normativa, y también la Ley impugnada responde a las necesidades del tiempo en que se ha dictado, que no es ya el del establecimiento e incipiente consolidación de los partidos políticos, sino el de la garantía del régimen plural de partidos frente a los grupos y asociaciones que pretendan desvirtuarlo con la utilización de medios violentos y al margen de la legalidad. 
La circunstancia, como reconoce el Abogado del Estado, de que "no cabe negar, puesto que es notorio", que la configuración de buena parte del art. 9 «se ha hecho teniendo en cuenta la trayectoria y actividad de un notorio partido político vasco, que ha dado lugar al primer supuesto de aplicación del procedimiento del art. 11 LOPP, en trámite cuando estas líneas se escriben", no significa a juicio del Tribunal, que se trate de una Ley de caso único. La percepción por el legislador orgánico de que una formación política determinada puede ser contraria, en su actividad y con sus comportamientos, al modelo de partido que tiene encaje y cobertura en la Constitución puede perfectamente erigirse en occasio para la adopción de una ley como la recurrida, pero lo que determinará su constitucionalidad o inconstitucionalidad no será el acierto de esa percepción circunstancial, sino el alcance objetivo de la ley finalmente adoptada, cuya ratino se limita a reflejar las inquietudes de la ocasión, sino que se acomoda a la racionalidad objetivada del ordenamiento constitucional.

7. El fundamento 16 resuelve la pretensión del recurrente en inconstitucionalidad de la retroactividad de la norma, y que se concreta en la disposición transitoria única, 1. En ella se establece que los partidos políticos inscritos en el Registro del Ministerio del Interior a la fecha de entrada en vigor de la Ley quedarán sujetos a la misma. Es en el apartado 2 donde el Gobierno Vasco denuncia un vicio de inconstitucionalidad por infracción del principio de irretroactividad (art. 9.3 CE). Con arreglo a ese apartado, a los efectos de aplicación del art. 9.4 LOPP (que relaciona los elementos utilizables para apreciar y valorar las actividades que pueden dar lugar a la disolución de un partido político) se considerará fraude de ley "la constitución, en fecha inmediatamente anterior o posterior a dicha entrada en vigor, de un partido político que continúe o suceda la actividad de otro, realizada con la intención de evitar la aplicación a éste de las disposiciones de esta Ley". La redacción del precepto no merece un juicio de inconstitucionalidad, pues queda claro que lo perseguido, en todo caso, es permitir la aplicación del art. 9.4 LOPP «a las actividades realizadas con posterioridad a la entrada en vigor de la presente Ley Orgánica", tal y como advierte la propia Disposición recurrida. Es decir, en ningún supuesto se prevé el enjuiciamiento de actividades y conductas anteriores a la Ley Orgánica 6/2002, de suerte que la Ley considera relevantes únicamente las posteriores a su entrada en vigor. 
Con otras palabras, por disposición expresa de la Ley, la totalidad del presupuesto que determina la disolución ha de llevarse a cabo bajo su vigencia. Tanto las actividades aisladamente consideradas como "la continuidad y repetición" a las que se refiere el art. 9.4 al que remite la disposición transitoria son posteriores a la entrada en vigor de la Ley Orgánica 6/2002. Y otra cosa es que, a efectos de determinar la significación de tales actividades y valorar su relevancia en el conjunto de la conducta del partido de que se trate (y exclusivamente a esos efectos, pues tener en cuenta la conducta anterior a la entrada en vigor de la Ley como base de la ilegalización sería inconstitucional por incurrir en la retroactividad prohibida por el art. 9.3 CE), pueda tomarse en consideración lo que la Ley llama "trayectoria" (art. 9.4 LOPP), que puede comprender comportamientos producidos con anterioridad a la entrada en vigor de la Ley; pero, eso no comporta ninguna clase de retroactividad prohibida por la Constitución.

Sentado lo anterior, en una primera lectura, el significado de la disposición transitoria única sería el de establecer una presunción de fraude ligada a la constitución de un partido político de cobertura en fechas inmediatamente anteriores o posteriores a la entrada en vigor de la Ley. Ese significado aparente podría pugnar con exigencias constitucionales, máxime en la medida en que se hallase ligado a la realización de actos anteriores a la tan repetida entrada en vigor. Sin embargo, desde el momento en que en el último inciso del precepto se dejan a la apreciación libre del Tribunal tanto el hecho de que un partido sea o no continuador o sucesor de otro cuanto la existencia o inexistencia de intención de defraudar, puede descartarse cualquier interpretación del mismo en términos de presunción de fraude. Así entendido, el precepto subraya que, si un partido continúa o sucede a otro, la trayectoria del sucedido, apreciado judicialmente el fraude, puede utilizarse también para determinar y valorar el sentido de los actos realizados después de la entrada en vigor de la Ley. En tales términos no es contrario a la Constitución.

8. El fundamento jurídico 17, es claro y conciso, en relación con las especialidades procesales de la Ley recurrida, manifestando el Tribunal que "no es de apreciar en ellas nada de lo que resulte algún fundamento para el pretendido carácter singular de su normativa. La disolución judicial de los partidos políticos que eventualmente incurran en las causas establecidas, de manera gene- 
ral y abstracta, en la Ley Orgánica 6/2002 será acordada, en todo caso, "por el órgano jurisdiccional competente» (art. 10.2 LOPP), respetándose así el mandato contenido en el art. 22.4 CE

9. En el fundamento jurídico 18 resuelve el Tribunal la pretensión inserta en el recurso del Gobierno Vasco, relativa a varios preceptos de la Ley Orgánica 6/2002 por la supuesta infracción del contenido del derecho de asociación garantizado por el art. 22 $\mathrm{CE}$, precepto que, para el demandante, conforma el núcleo básico del régimen constitucional de los partidos. En del gobierno Vasco, el art. 1 LOPP sería inconstitucional por limitar a los españoles el derecho de crear partidos políticos, pues se discrimina así a los nacionales de los Estados miembros de la Unión Europea, que, siendo titulares del derecho de sufragio activo y pasivo en las elecciones municipales y europeas, se ven privados, injustificadamente, de un derecho que se reserva a quienes, en esos comicios, son sus iguales. Con carácter más general, se discriminaría también a todos los extranjeros, y no sólo a los nacionales de la Unión, ya que el art. 2 LODA extiende a todos el derecho de crear asociaciones y nada justifica que la Ley recurrida se separe en ese punto de lo dispuesto en la legislación común.

A juicio del Tribunal, se impone aquí determinar si la Constitución permite limitar a los españoles el derecho de crear partidos políticos. Como alega el Gobierno Vasco, el art. 2.2 LODA reconoce a "todas las personas" el derecho a asociarse libremente para la consecución de fines lícitos, asumiendo así el legislador orgánico la doctrina que sobre el particular ya quedó sentada en la STC 115/1987, de 7 de julio. Las razones que abonan esa generalización del derecho cuando de asociaciones comunes se trata no concurren, sin embargo, en el caso de los partidos políticos, precisamente en razón de cuanto hace de éstos unas asociaciones cualificadas por la relevancia constitucional de sus funciones. En efecto, los partidos políticos son instrumento privilegiado de participación política, actividad ésta cuyo ejercicio se constituye en un derecho que, garantizado por el art. $23 \mathrm{CE}$, tiene por titulares únicamente a los españoles (art. 13.2 CE). Ciertamente, el propio art. 13.2 CE hace a renglón seguido la salvedad de que para determinados comicios puede reconocerse, en ciertas condiciones, el derecho de sufragio a los extranjeros. Pero ello no desvirtúa el hecho de que con esa salvedad se excepciona lo que constituye un principio, a saber, que 
la participación en los asuntos públicos atañe únicamente a los nacionales españoles, por cuanto con esa actividad se provee a la integración de órganos representativos que "ostentan potestades atribuidas directamente por la Constitución y los Estatutos de Autonomía y ligadas a la titularidad por el pueblo español de la soberanía" (Declaración del Tribunal Constitucional de 1 de julio de 1992, FJ 3.c).

10.En el fundamento 19 resuelve el Tribunal el argumento del Gobierno Vasco en relación con el último inciso del art. 2.1 LOPP, en cuya virtud no pueden ser promotores de un partido político quienes «hayan sido penalmente condenados por asociación ilícita o por alguno de los delitos graves previstos en los Títulos XXI a XXIV del Código Penal». En su opinión, se impone una pena accesoria ex leg, do que no tendría fácil acomodo en el art. $25 \mathrm{CE}$ y, en todo caso, sería contrario al principio de proporcionalidad, pues no se atiende a la distinta entidad de los diferentes delitos contemplados en los Títulos del Código penal a los que se remite el precepto y se restringe gravemente el derecho fundamental de asociación.

Para el Tribunal, la prohibición impugnada no es, en puridad, una pena o sanción añadida a las impuestas por la comisión de los delitos reseñados, sino, como todas las que integran el art. 2.1 LOPP, un requisito de capacidad. En términos positivos, quienes se encuentren en la situación descrita en el precepto estarán incursos en una causa de incapacidad especial que sólo dejará de afectarles cuando "hayan sido judicialmente rehabilitados». En tanto que requisito de capacidad para promover un partido político, la circunstancia de haber sido condenado, y aún no rehabilitado, por la comisión de los delitos graves previstos en los Títulos XXI a XXIV del Código penal no resulta exorbitante en términos de respeto al principio de proporcionalidad. No ya porque, no siendo una sanción, quede de entrada al margen la lógica de ese principio, sino porque ni siquiera desde esa perspectiva resulta injustificable que se incapacite para promover un partido político a quien ha sido condenado (y condenado sin haber alcanzado la rehabilitación judicial) por los delitos graves (y sólo por los delitos graves del art. 13.1 CP) tipificados en aquellos Títulos, todos relacionados con la actividad política y acreditativos de una identificación con la violencia y un desprecio por los procedimientos legalmente establecidos que justificadamente anticipan la defensa del orden constituido mediante la prohibición de que cree un instrumento cualificado de participación en la vida públi- 
ca quien todavía no ha expiado por entero la condena impuesta por haber atentado contra la pacífica convivencia en que aquélla debe desenvolverse. $Y$ ello sin que pueda perderse de vista la circunstancia de que el así incapacitado no se ve privado de todas las variantes que integran el contenido de su derecho de participación política, pues la Ley recurrida no le impide la afiliación a un partido ya constituido ni coarta en ningún sentido su derecho de sufragio, de manera que, atendidos su alcance y su sentido, la previsión legal no resulta desproporcionada.

11. El fundamento jurídico vigésimo primero analiza la impugnación del Gobierno Vasco del régimen de constitución e inscripción registral de partidos establecido por la Ley Orgánica 6/2002. En primer lugar, el hecho de que la inscripción tenga carácter constitutivo (art. 3.2), lo que contradice al art. 22.3 CE, que sólo contempla la inscripción a efectos de publicidad, y supone una nueva e injustificada divergencia frente a las previsiones de la LODA. El carácter constitutivo de la inscripción "contaminaría» también, en la opinión del recurrente, otras previsiones de la Ley impugnada, en concreto las referidas a la intervención de la Administración en el procedimiento de inscripción, a la que se dispensa una posición privilegiada en el incidente de ejecución previsto en el art. 12.3 LOPP y que, en todo caso, puede entorpecer el proceso de adquisición de personalidad jurídica por el partido y con ello dificultar gravemente el ejercicio del derecho de asociación.

En este sentido estable el Tribunal que la supuesta contradicción entre el art. 22.3 CE, que dispone que la inscripción de las asociaciones en el registro tendrá lugar "a los solos efectos de la publicidad» y el art. 3.2 LOPP que liga a dicha inscripción la adquisición de personalidad jurídica por parte de los partidos, hemos de partir de la idea de que la ratide la prohibición de que el registro sirva a otros efectos que los de la publicidad reside en la tutela de la libertad de creación de asociaciones y partidos, con la que ninguna relación guarda el hecho de que se adquiera o no la personalidad jurídica. Por lo tanto, el legislador es libre de asociar o no el nacimiento de la personalidad jurídica a la inscripción en el registro sin que del art. 22.3 derive ningún impedimento para ello.

De esta forma, y a juicio del Tribunal, el régimen diseñado por la Ley Orgánica 6/2002 en este concreto aspecto, en cuanto supedita la adquisición de personalidad jurídica del partido político a la 
previa inscripción en el Registro del Ministerio del Interior, no implica per seque haya de considerarse como un acto de injerencia de la Administración estatal contrario al principio constitucional de libertad de creación o constitución de partidos políticos. Para que ello ocurra y, por ende, pudiera prosperar la impugnación del Gobierno Vasco en este concreto extremo, sería menester que, por el modo en que el legislador regula el acto de inscripción y por las facultades que para ello atribuye al Ministerio del Interior, se apreciase que a este se le apodera de un efectivo control material sobre la procedencia o no de la inscripción solicitada $y$, por tanto, sobre la atribución de personalidad jurídica al partido, de tal manera que las facultades de dicho Departamento ministerial excedieran del estricto y limitado ámbito de la simple verificación reglada de los aspectos jurídicoformales de la documentación presentada a inscripción, tal como lo ha entendido la doctrina constitucional, pues como declaró la STC 85/1986, de 25 de junio, FJ 3.

De esta forma, y en última instancia, el legislador orgánico no apodera a la Administración estatal, mediante la inscripción registral, con facultades de un verdadero control material en orden a la personificación jurídica de los partidos políticos, por lo que no cabe hablar de que se desconoce o menoscaba el aludido principio constitucional de libertad de creación de partidos políticos plasmado en el art. 6 de la Constitución.

12. Por último, el Tribunal Constitucional analiza la impugnación del Gobierno Vasco del art. 12.3 LOPP, precepto que se inscribe en el ámbito de los efectos de la disolución judicial ya declarada de un partido político, tal como aparece en la rúbrica del mismo. El efecto específico que señala el concreto apartado objeto de impugnación es el de atribuir a la Sala sentenciadora, previa audiencia de los interesados, el concreto pronunciamiento de «declarar la improcedencia de la continuidad o sucesión de un partido disuelto a la que se refiere el párrafo b) del apartado 1", es decir, el de impedir la creación de un nuevo partido político o la utilización de otro ya inscrito en el Registro en tanto en cuanto aquel continúe o suceda la actividad de un anterior partido declarado ilegal y ya disuelto. Para que la Sala que acordó la disolución pueda emitir tal pronunciamiento, se atribuye legitimación para así instarlo de aquella, además de a quienes fueron partes en el proceso en que se dictó sentencia de disolución, al Ministerio del Interior y al Ministerio Fiscal, siempre y cuando —como especifica el precep- 
to en su inciso final- el nuevo partido que continúe o suceda la actividad del anterior pretenda su inscripción en el Registro y consiguiente atribución de personalidad jurídica.

El Gobierno Vasco reprocha inconstitucionalidad al referido precepto por entender que, en el mencionado incidente de ejecución previsto en el art. 12.3 LOPP, se otorgan a la Administración, dada "la presencia del Ministerio del Interior en dicho incidente", facultades que exceden de la función de mero control o verificación reglada de los aspectos formales de la constitución del partido político, para caer en el proscrito ámbito de las injerencias ilegítimas de la Administración en relación con el derecho fundamental que trata de ejercitarse. Añade el demandante que el Ministerio del Interior no se limita a su condición de parte en dicho incidente procesal sino que es sujeto titular de la acción, en cuanto se le faculta directamente por la Ley para activarlo.

Recuerda en este apartado el Tribunal Constitucional, que la Ley parte de que el Ministerio del Interior carece de facultades, como es constitucionalmente adecuado, para denegar la inscripción con base en la real o supuesta continuidad o sucesión a que alude el precepto. Siendo ello así, el atribuirle legitimación para instar el referido pronunciamiento no supone apoderarlo con facultades decisorias que impliquen una injerencia ilegítima en el ejercicio del derecho fundamental, pues en definitiva, la apreciación de si procede impedir, con dicha base jurídica, la creación e inscripción del nuevo partido, corresponde a la Sala que dictó sentencia de disolución en el que pudiéramos denominar proceso principal, con arreglo a los criterios que el mismo precepto enuncia.

Por lo manifestado, estima el Tribunal que "hemos de concluir que el art. 12.3 LOPP no contradice el texto constitucional, de manera que no procede acoger la pretensión impugnatoria ejercitada frente al mismo por el Gobierno Vasco».

En virtud de los fundamentos jurídicos relacionados, el Tribunal decide:

\section{Rechazar la causa de inadmisión invocada por el Abogado del Estado.}

\section{2ํㅡㄹ Destimar el presente recurso de inconstitucionalidad.}

Finaliza la sentencia, precisando el alcance del fallo, y de forma concreta establece que "las consideraciones anteriores determinan la pro- 
cedencia de la desestimación del recurso, puntualizando que los artículos 3.1, 5.1, 9.2 y 3, y la disposición transitoria única, apartado 2, de la Ley Orgánica de partidos políticos sólo son constitucionales si se interpretan en los términos señalados en los fundamentos jurídicos 10, 11, 12, 13, 16, 20 y 21 de esta Sentencia. 